\title{
Changes in vitamin-D metabolites and parathyroid hormone in plasma following cholecalciferol administration to pre- and postmenopausal women in the Netherlands in early spring and to postmenopausal women in Curaçao
}

\author{
BY FIONA R. M. VAN DER KLIS ${ }^{1}$, JAN H.P. JONXIS ${ }^{2}{ }^{*}$ JASPER J. VAN \\ DOORMAAL ${ }^{3}$, PETER SIKKENS ${ }^{4}$, ALEJANDRO E. C. SALEH \\ AND FRITS A. J. MUSKIET ${ }^{1} \uparrow$ \\ ${ }^{1}$ Central Laboratory for Clinical Chemistry, University Hospital Groningen, Oostersingel 59, \\ PO Box 30.001, 9700 RB Groningen, The Netherlands \\ ${ }^{2}$ Retired Professor of Paediatrics, Rijksstraatweg 65, 9752 AC Haren, The Netherlands \\ ${ }^{3}$ Department of Internal Medicine, University Hospital Groningen, The Netherlands \\ ${ }^{4}$ Hoofdweg 86, 9761 EK Eelde, The Netherlands \\ ${ }^{5}$ Department of Internal Medicine, St Elisabeth Hospital, Willemstad, Curaçao, \\ The Netherlands Antilles
}

(Received 6 March 1995 - Revised 5 July 1995-Accepted 8 August 1995)

\begin{abstract}
To study the effect on plasma 25 -hydroxycholecalciferol $(25(\mathrm{OH}) \mathrm{D}), 1,25$-dihydroxycholecalciferol $\left(1,25(\mathrm{OH})_{2} \mathrm{D}\right)$ and parathyroid hormone (PTH) we supplemented premenopausal (aged 30 (SD 7 ) years) and postmenopausal (aged 61 (SD 2) years) white women living in The Netherlands in late winter/early spring, and elderly black and white women (aged 75 (SD 6) years) living in Curaçao (Dutch Antilles) with either 10 or $20 \mu \mathrm{g}$ cholecalciferol/d for 4,5 and 9 weeks respectively. Baseline plasma 25(OH)D concentration of Dutch women was lower than that of Curaçao women. Postmenopausal Dutch women had a higher PTH concentration in plasma than premenopausal Dutch and postmenopausal Curaçao women. There were no differences in plasma $1,25(\mathrm{OH})_{2} \mathrm{D}$. Cholecalciferol administration increased 25(OH)D in all groups, $1,25(\mathrm{OH})_{2} \mathrm{D}$ in postmenopausal Curaçao women and PTH in postmenopausal Curaçao women and premenopausal Dutch women. Serum and urinary $\mathrm{Ca}$ and phosphate concentrations did not change. There were no response differences between 10 and $20 \mu \mathrm{g}$ doses. Oral cholecalciferol administration (either $10 \mathrm{or} 20 \mu \mathrm{g} / \mathrm{d}$ ) to women living at northern latitudes in late winter/early spring increased $25(\mathrm{OH}) \mathrm{D}$ levels to the baseline levels of elderly people living in the tropics.
\end{abstract}

Cholecalciferol: Parathyroid hormone: Osteoporosis

Vitamin-D deficiency is rare among people living in tropical climates as long as they regularly expose themselves to sunlight. We recently reported (Dubbelman et al. 1993; Jonxis et al. 1993) higher 25-hydroxycholecalciferol (25(OH)D) and somewhat higher 1, 25dihydroxycholecalciferol $\left(1,25(\mathrm{OH})_{2} \mathrm{D}\right)$ plasma levels in postmenopausal white women living in the tropics (Curaçao, The Netherlands Antilles; $12.15^{\circ}$ north latitude), compared with counterparts living at more northerly latitudes (The Netherlands; $52^{\circ}$ north). (In the present paper, for the sake of simplicity, women living in The Netherlands and Curaçao are

\footnotetext{
* Professor Jonxis died on 26 July 1995.

$\uparrow$ For reprints.
} 
described as 'Dutch' and 'Curaçao' women respectively, although all of them have Dutch nationality.) Vertebral compression fractures commonly encountered in postmenopausal white women living at higher latitudes were absent in Curaçao counterparts. These differences may be explained by the abundant sunlight in the tropics all the year round, which, in contrast to higher latitudes, favours year-long vitamin-D synthesis. We suggested that cholecalciferol administration to women from the menopause onwards and possibly also to elderly men, in an amount that raises plasma $25(\mathrm{OH}) \mathrm{D}$ levels to those of Curaçao women, may delay the occurrence of osteoporotic lesions. In the present study we investigated whether cholecalciferol administration to premenopausal and postmenopausal Dutch women would raise late winter/early spring plasma $25(\mathrm{OH}) \mathrm{D}$ levels to baseline $25(\mathrm{OH}) \mathrm{D}$ levels seen in Curaçao.

\section{SUBJECTS AND METHODS}

\section{Subjects}

A total of 105 women were enrolled in the study. They were ambulatory and had no major ailments. They comprised: (1) forty-one (twenty black, twenty-one white) postmenopausal Curaçao women, aged 64-89 years, mean 75.3 (SD 5.8) years; (2) fifty-eight postmenopausal white Dutch women, aged 54-65 years, mean $61 \cdot 2$ (SD 2.4) years, and (3) six apparently healthy premenopausal white Dutch women, aged 23-40 years, mean 30.1 (SD 6.9) years. Five of the premenopausal women took oral contraceptives.

None of the women used drugs known to alter vitamin-D or bone metabolism (e.g. anticonvulsants, corticosteroids and postmenopausal oestrogens). Informed consent was obtained from all subjects. The study was in agreement with local ethical standards and the Helsinki declaration of 1975, as revised in 1989.

\section{Study design}

The women having supplementary cholecalciferol received 10 or $20 \mu \mathrm{g}$ oral cholecalciferol (Duphar bv, The Netherlands)/d. Twenty postmenopausal Dutch women were given a placebo. The women were randomly assigned to receive placebo, 10 or $20 \mu \mathrm{g}$ cholecalciferol/d.

Postmenopausal black (n 20) and white (n 21) Curaçao women. Supplementary cholecalciferol was given for 9 weeks (from October to December 1992). Ten black and ten white women received $20 \mu \mathrm{g} / \mathrm{d}$ as a single dose. Ten black and eleven white women received an equal daily amount, administered as two doses of $10 \mu \mathrm{g}$ during the day. Plasma $25(\mathrm{OH}) \mathrm{D}$, $1,25(\mathrm{OH})_{2} \mathrm{D}$ and parathyroid hormone $(\mathrm{PTH})$, serum $\mathrm{Ca}$ and phosphate, and urinary $\mathrm{Ca}$, phosphate and creatinine concentrations were determined before and after 1, 5 and 9 weeks supplementation.

Postmenopausal white Dutch women (n 58). Cholecalciferol was administered for 5 weeks in late winter/early spring (from 6 April to 13 May 1993). The women received daily doses of $20 \mu \mathrm{g}$ cholecalciferol ( $n$ 19), $10 \mu \mathrm{g}$ cholecalciferol ( $n$ 19), or $135 \mathrm{mg}$ cellulose (placebo; $n 20)$. To avoid detection of dissimilarity between supplements, cholecalciferol was administered in cellulose-filled capsules that resembled the placebo. Plasma $25(\mathrm{OH}) \mathrm{D}$, $1,25(\mathrm{OH})_{2} \mathrm{D}$ and $\mathrm{PTH}$, and serum $\mathrm{Ca}$ and phosphate concentrations of all women were determined before and after 5 weeks supplementation.

Premenopausal white Dutch women (n 6). Cholecalciferol was administered for 4 weeks in late winter (from $4 \mathrm{March}$ to 1 April 1992). The women received $20 \mu \mathrm{g}$ cholecalciferol daily. Plasma $25(\mathrm{OH}) \mathrm{D}, 1,25(\mathrm{OH})_{2} \mathrm{D}$ and PTH were determined before and after 4 weeks. Serum $\mathrm{Ca}$ and phosphate were measured weekly. 


\section{Sampling, sample processing and analytical methods}

Blood and EDTA-anticoagulated blood were collected by venepuncture for the preparation of serum and plasma respectively. Samples of urine were collected after morning voidance and after a subsequent $2 \mathrm{~h}$ fast. These were either analysed immediately or stored at $-20^{\circ}$ until analysed. Serum and urinary $\mathrm{Ca}$ and phosphate concentrations of the Curaçao women were determined in the local Public Health Laboratory. Plasma, serum and urine remainders were transported to The Netherlands in solid $\mathrm{CO}_{2}$ for further analysis in the University Hospital Groningen.

Serum and urinary $\mathrm{Ca}$ (ortho cresolphthalein complexone method) and phosphate (molybdate method), and urinary creatinine (picric acid method) were measured with a Kodak Ektachem 500 (Eastman Kodak Company, Rochester, NY, USA) in The Netherlands and a Beckman Astra-8 autoanalyser (Beckman, Fullerton, CA, USA) in Curaçao. Reference ranges for serum $\mathrm{Ca}$ and phosphate were: $2 \cdot 25-2 \cdot 75$ and $0.74-1.52 \mathrm{mmol} / 1$ (The Netherlands), and $2 \cdot 20-2.60$ and $0.70-1.60 \mathrm{mmol} / 1$ (Curaçao) respectively. Between-series coefficients of variation (CV) for serum $\mathrm{Ca}$ and phosphate concentrations in the reference ranges amounted to : 1.2 and 1.5\% (The Netherlands) and 1.5 and $2.0 \%$ (Curaçao) respectively. Intact PTH (PTH amino acids 1-84) was measured with a two-site immunoradiometric assay (IRMA) by using the commercial kit of the Incstar Corporation (Stillwater, MN, USA). The between-series CV for quality-control samples at $3.4,20.0$ and $32.5 \mathrm{pmol} / 1$ were $9 \cdot 2,9 \cdot 2$ and $9.6 \%$ respectively. $25(\mathrm{OH}) \mathrm{D}_{2}$ and $25(\mathrm{OH}) \mathrm{D}_{3}$ were measured as $25(\mathrm{OH}) \mathrm{D}$, by using solid-phase prepurification followed by a competitive radio-binding assay with tritium-labelled $25(\mathrm{OH}) \mathrm{D}_{3}$ and vitamin D-binding protein from human serum. Between-series $\mathrm{CV}$ at 16, 62 and $101 \mathrm{nmol} / 1$ were 13, 12 and $13 \%$ respectively. $1,25(\mathrm{OH})_{2} \mathrm{D}_{2}$ and $1,25(\mathrm{OH})_{2} \mathrm{D}_{3}$ were determined as $1,25(\mathrm{OH})_{2} \mathrm{D}$ with the kit of the Incstar Corporation, based on solid-phase prepurification followed by a competitive radioreceptor assay with tritium-labelled $1,25(\mathrm{OH})_{2} \mathrm{D}_{3}$ and a thymus receptor. The between-series $\mathrm{CV}$ at 25,93 , and $138 \mathrm{pmol} / 1$ were 21,16 , and $14 \%$ respectively.

\section{Statistical analyses}

Independent $t$ tests were used for establishing between-group differences before supplementation (Table 1). Values of $P<0.05$ were considered significant. Longitudinal results from the Curaçao study were analysed by repeated measurement (ANOVA; Stevens, 1986). Values that showed supplementation effects were subsequently investigated by the modified Tukey post-hoc procedure for one-sample repeated measurements at $P<$ 0.05 . After verification of parallel line assumption, coincidences of analyte courses of different Curaçao groups (black v. white; $2 \times 10$ v. $20 \mu \mathrm{g}$ ) were tested with repeated measurement analysis. Dependent $t$ tests were used for longitudinal data from the two Dutch studies. Values of $P<0.05$ were considered significant. For between-group comparison of data obtained from two sampling points during the study, analyses of covariance (ANCOVA) were used, with time as covariate. An example is the analysis of differences in $25(\mathrm{OH}) \mathrm{D}$ courses of postmenopausal Curaçao and Dutch women from baseline to 4-5 weeks supplementation.

\section{RESULTS}

Baseline values

Baseline values for plasma $25(\mathrm{OH}) \mathrm{D}, 1,25(\mathrm{OH})_{2} \mathrm{D}$ and $\mathrm{PTH}$ of women in all groups are given in Table 1. The black and white postmenopausal Curaçao women taking part in the study did not differ in age, or in plasma $25(\mathrm{OH}) \mathrm{D}, 1,25(\mathrm{OH})_{2} \mathrm{D}$ and PTH concentrations. 
Table 1. Plasma 25-hydroxycholecalciferol (25(OH)D), 1,25-dihydroxycholecalciferol $\left(1,25(\mathrm{OH})_{2} \mathrm{D}\right)$ and parathyroid hormone $(\mathrm{PTH})$ concentrations in postmenopausal black and white Curaçao women, and postmenopausal and premenopausal white Dutch women in late winter

(Mean values and standard deviations)

\begin{tabular}{|c|c|c|c|c|c|c|c|c|c|}
\hline & \multirow[b]{2}{*}{$n$} & \multicolumn{2}{|c|}{$\begin{array}{c}\text { Age } \\
\text { (years) }\end{array}$} & \multicolumn{2}{|c|}{$\begin{array}{c}25(\mathrm{OH}) \mathrm{D} \\
(\mathrm{nmol} / \mathrm{l})\end{array}$} & \multicolumn{2}{|c|}{$\begin{array}{l}1,25(\mathrm{OH})_{2} \mathrm{D} \\
(\mathrm{pmol} / \mathrm{l})\end{array}$} & \multicolumn{2}{|c|}{$\begin{array}{c}\text { PTH } \\
(\mathrm{pmol} / 1)\end{array}$} \\
\hline & & Mean & SD & Mean & SD & Mean & SD & Mean & SD \\
\hline Post Cur, black & 20 & $73 \cdot 8$ & $4 \cdot 0$ & $88 \cdot 3$ & $28 \cdot 2$ & $98 \cdot 0$ & $53 \cdot 5$ & $2 \cdot 3$ & $1 \cdot 3$ \\
\hline Post Cur, white & 21 & $75 \cdot 4$ & $7 \cdot 1$ & $82 \cdot 0$ & $25 \cdot 8$ & $78 \cdot 6$ & $46 \cdot 3$ & 1.9 & $1 \cdot 1$ \\
\hline Post Cur, all & 41 & $75 \cdot 3$ & 5.8 & $85 \cdot 1$ & 26.9 & $88 \cdot 3$ & $50 \cdot 4$ & $2 \cdot 1$ & $1 \cdot 2$ \\
\hline Post Neth & 58 & $61 \cdot 2^{* * *} \dagger$ & $2 \cdot 4$ & $58 \cdot 5^{* * *} \uparrow$ & $23 \cdot 8$ & $91 \cdot 7$ & $32 \cdot 1$ & $3.9 * * * \dagger$ & $1 \cdot 3$ \\
\hline Pre Neth & 6 & $30 \cdot 1^{* * *}$ & 69 & $46 \cdot 2^{* * *}$ & $13 \cdot 3$ & 81.9 & $29 \cdot 6$ & 1.9 & $1 \cdot 4$ \\
\hline
\end{tabular}

Post, postmenopausal; Pre, premenopausal; Cur, Curaçao; Neth, The Netherlands; Post Cur all, pooled data from black and white postmenopausal women in Curaçao.

*** Mean values were significantly different from pooled value for black and white postmenopausal women in Curaçao $(P<0.001)$.

$\dagger$ Mean values were significantly different from those for premenopausal women in The Netherlands $(P<0.02)$.

For comparison with values for premenopausal and postmenopausal Dutch women the Curaçao women were, therefore, considered as a single group.

Plasma 25(OH)D concentration of the elderly Curaçao women was higher than that of the young and elderly Dutch women and plasma $25(\mathrm{OH}) \mathrm{D}$ concentration of the elderly Dutch women was higher than that of the young Dutch women.

There were no differences in plasma $1,25(\mathrm{OH})_{2} \mathrm{D}$ between the groups. Plasma PTH of the elderly Dutch women was higher than that of the young Dutch women and of the elderly Curaçao women. Premenopausal Dutch women and the elderly Curaçao women did not differ in plasma PTH. Baseline serum $\mathrm{Ca}$ and phosphate of all women, and urinary $\mathrm{Ca}$ :creatinine, phosphate: creatinine and $\mathrm{Ca}$ :phosphate ratios of postmenopausal Curaçao women were within the reference ranges of our laboratory.

\section{Effects of cholecalciferol and placebo}

Fig. 1 shows the changes in plasma $25(\mathrm{OH}) \mathrm{D}, 1,25(\mathrm{OH})_{2} \mathrm{D}$ and PTH following cholecalciferol supplementation of postmenopausal black and white Curaçao women (a), postmenopausal Dutch women (b) and premenopausal Dutch women (c). The changes in plasma $25(\mathrm{OH}) \mathrm{D}, 1,25(\mathrm{OH})_{2} \mathrm{D}$ and $\mathrm{PTH}$ following placebo administration to postmenopausal Dutch women are given in Fig. 2.

Postmenopausal Curaçao women. There were no significant differences in baseline plasma $25(\mathrm{OH}) \mathrm{D}, 1,25(\mathrm{OH})_{2} \mathrm{D}$ or PTH concentrations between black $(n 20)$ and white $(n 21)$ postmenopausal Curaçao women. Changes following cholecalciferol administration were also similar in the two groups, and similar also whether the vitamin was taken as $20 \mu \mathrm{g}$ once daily or in two doses of $10 \mu \mathrm{g}$ (results not shown). Black and white postmenopausal Curaçao women were therefore considered as a single group (Fig. 1(a)). The pooled data showed that supplementation caused statistically significant increases of $25(\mathrm{OH}) \mathrm{D}$, $1,25(\mathrm{OH})_{2} \mathrm{D}$ and PTH. Stable levels were reached within 1 week. Serum $\mathrm{Ca}$ and phosphate, and urinary $\mathrm{Ca}$ :creatinine, phosphate:creatinine and $\mathrm{Ca}$ :phosphate ratios did not change. Mean serum concentrations at baseline and after 9 weeks supplementation were: $\mathrm{Ca}$ 

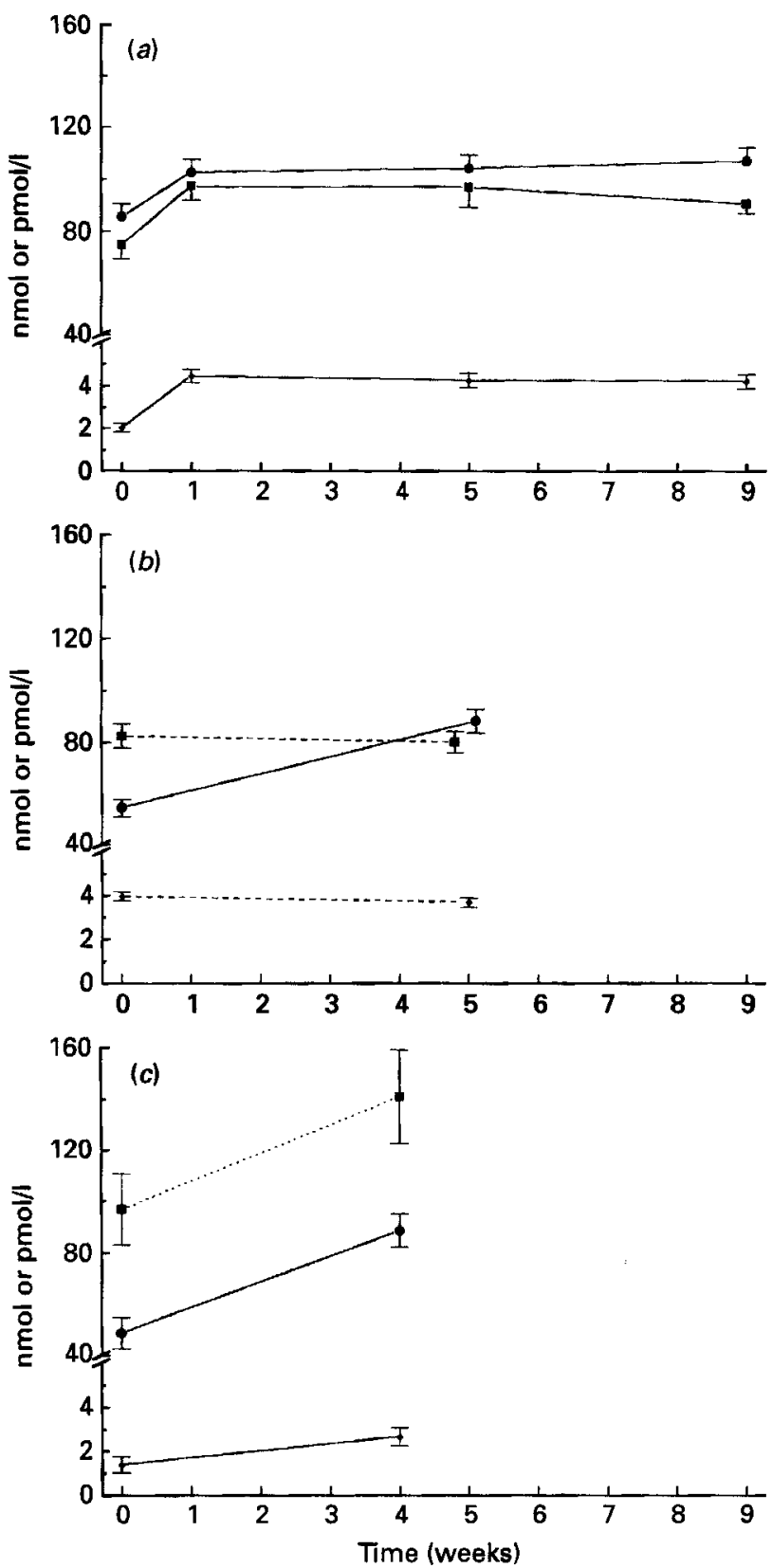

Fig. 1. Courses of plasma 25-hydroxycholecalciferol $(25(\mathrm{OH}) \mathrm{D} ;), 1,25$-dihydroxycholecalciferol $\left(1,25(\mathrm{OH})_{2} \mathrm{D}\right.$; D) and parathyroid hormone (PTH; $\bullet$ ) concentration in (a) postmenopausal black $(n 20)$ and white $(n 21)$ Curaçao women, (b) postmenopausal white Dutch women $(n 38)$ and (c) premenopausal white Dutch women $(n 6)$ following cholecalciferol supplementation (10 or $20 \mu \mathrm{g} / \mathrm{d}$ ). Values for $25(\mathrm{OH}) \mathrm{D}$ are nmol/1; those for $1,25(\mathrm{OH})_{2} \mathrm{D}$ and PTH are pmol/1. For details of subjects and procedures see pp. 638-639. Values are means with their standard errors represented by vertical bars. Repeated measurements statistics and dependent $t$ tests revealed timedependent increases of $25(\mathrm{OH}) \mathrm{D}$ levels in all groups, of $1,25(\mathrm{OH})_{2} \mathrm{D}$ in postmenopausal Curaçao women, and of PTH levels in postmenopausal Curaçao women and premenopausal Dutch women (uninterrupted lines). 


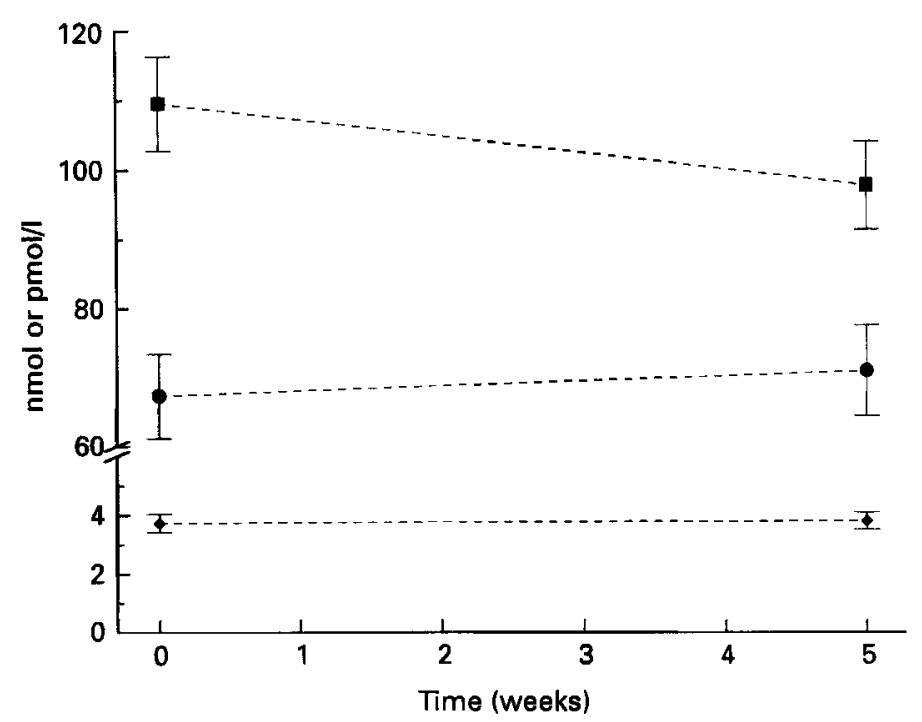

Fig. 2. Courses of plasma 25-hydroxycholecalciferol $(25(\mathrm{OH}) \mathrm{D} ; \mathrm{O}), 1,25$-dihydroxycholecalciferol $\left(1,25(\mathrm{OH})_{2} \mathrm{D}\right.$; D) and parathyroid hormone (PTH; $\bullet$ ) concentration following administration of cellulose (placebo) to postmenopausal white Dutch women $(n 20)$. For details of subjects and procedures see pp. 638-639. Values for $25(\mathrm{OH}) \mathrm{D}$ are $\mathrm{nmol} / \mathrm{l}$; those for $1,25(\mathrm{OH})_{2} \mathrm{D}$ and $\mathrm{PTH}$ are pmol/l. Values are means with their standard errors represented by vertical bars. Repeated measurements statistics and dependent $t$ tests revealed no changes.

$2.30(\mathrm{SD} 0.20)$ and $2.47(\mathrm{SD} 0.11) \mathrm{mmol} / 1$ and phosphate $1.16(\mathrm{SD} \mathrm{0.15})$ and $1 \cdot 13($ SD $0 \cdot 15) \mathrm{mmol} / \mathrm{l}$ respectively.

Postmenopausal Dutch women. Baseline values of $25(\mathrm{OH}) \mathrm{D}, 1,25(\mathrm{OH})_{2} \mathrm{D}$ and PTH, and their changes during cholecalciferol supplementation were not different for postmenopausal Dutch women who received 10 ( $n$ 19) or $20(n 19) \mu \mathrm{g} / \mathrm{d}$ (results not shown). The pooled data showed that $25(\mathrm{OH}) \mathrm{D}$, but not $1,25(\mathrm{OH})_{2} \mathrm{D}$ and PTH, increased (Fig. 1(b)). There were no significant changes in the twenty postmenopausal Dutch women receiving placebo (Fig. 2). Administration of cholecalciferol or placebo did not affect serum $\mathrm{Ca}$ and phosphate. Mean serum concentrations for vitamin-D-supplemented women at baseline and after 5 weeks were: $\mathrm{Ca} 2.47$ (SD 0.20) and 2.44 (SD 0.15) $\mathrm{mmol} / 1$ and phosphate $1.23(\mathrm{SD} 0 \cdot 19)$ and $1 \cdot 26(\mathrm{SD} 0 \cdot 12) \mathrm{mmol} / 1$ respectively.

Premenopausal Dutch women. In premenopausal women receiving cholecalciferol the $25(\mathrm{OH}) \mathrm{D}$ and $\mathrm{PTH}$ levels rose markedly, whereas $1,25(\mathrm{OH})_{2} \mathrm{D}$ levels did not change (Fig. 1(c)). Their serum $\mathrm{Ca}$ and phosphate concentrations did not change. Mean serum concentrations at baseline and after 4 weeks were: $\mathrm{Ca} 2 \cdot 41$ (SD 0.13) and 2.50 (SD 0.08) $\mathrm{mmol} / \mathrm{l}$ and phosphate 1.07 (SD 0.07) and 1.13 (SD 0.12) mmol/1 respectively.

Changes and endpoints in plasma $25(\mathrm{OH}) \mathrm{D}$ following cholecalciferol supplementation. Following 5 weeks supplementation with 10 or $20 \mu \mathrm{g}$ cholecalciferol/d, postmenopausal Dutch women reached mean plasma $25(\mathrm{OH}) \mathrm{D}$ levels of 87.9 (SD 28.1) nmol/1 ( $n$ 38). These levels were not significantly different from baseline levels of postmenopausal Curaçao women (mean 85.1 (SD 26.9) nmol/1; $n$ 41; Table 1). They were, however, lower than $25(\mathrm{OH}) \mathrm{D}$ levels of postmenopausal Curaçao women after 5 weeks supplementation with 20 or $2 \times 10 \mu \mathrm{g} / \mathrm{d}$ (mean $102.6(\mathrm{SD} 28.8) \mathrm{nmol} / \mathrm{l} ; n 41)$. The changes in plasma $25(\mathrm{OH}) \mathrm{D}$ of postmenopausal and premenopausal Dutch women were similar (parallel, coincident), but both significantly different from those of postmenopausal Curaçao women (parallel, but not coincident). 


\section{DISCUSSION}

Plasma 25(OH)D concentration usually decreases with advancing age, a condition associated with development of secondary hyperparathyroidism and increasing osteoporosis risk (Khaw et al. 1992). Nevertheless, compared with their significantly younger Dutch counterparts the postmenopausal women in Curaçao had higher plasma $25(\mathrm{OH}) \mathrm{D}$, lower PTH and similar $1,25(\mathrm{OH})_{2} \mathrm{D}$ concentrations (Table 1). These findings are at variance with those of our previous study (Dubbelman et al. 1993) in which postmenopausal women in Curaçao had higher $25(\mathrm{OH}) \mathrm{D}$, similar PTH and higher $1,25(\mathrm{OH})_{2} \mathrm{D}$ concentrations. A possible explanation is that the present postmenopausal Dutch women $(61.2$ (SD 2.4 ) years) were considerably younger than their previously studied institutionalized Dutch counterparts (63-83 years). Compared with our previous findings from premenopausal Dutch women the present group of premenopausal Dutch women showed similar plasma $25(\mathrm{OH}) \mathrm{D}, 1,25(\mathrm{OH})_{2} \mathrm{D}$, and PTH concentrations. Those of $25(\mathrm{OH}) \mathrm{D}$ and $1,25(\mathrm{OH})_{2} \mathrm{D}$ were found to be lower, compared with Curaçao counterparts (Dubbelman $e t$ al. 1993). Following 4 weeks vitamin-D supplementation, premenopausal Dutch women exhibited still lower $25(\mathrm{OH}) \mathrm{D}$, but somewhat higher $1,25(\mathrm{OH})_{2} \mathrm{D}$ and PTH concentrations, compared with baseline values of premenopausal Curaçao women (Dubbelman et al. 1993).

Higher plasma $25(\mathrm{OH}) \mathrm{D}$ concentrations in Curaçao are caused by year-long, seasonindependent, abundant sunlight, which favours vitamin-D synthesis in skin. Curaçao is a tropical island located in the Caribbean sea at $12^{\circ}$ north latitude. The island is predominantly inhabited by subjects of West-African origin. Most white women are of Dutch descent. Dietary habits are essentially Western, with a generally low intake of $\mathrm{Ca}$ because of low milk consumption.

We did not observe differences in baseline plasma 25(OH)D concentrations of black and white postmenopausal Curaçao women. This finding is in agreement with a study of Meier et al. (1991), who found similar 25(OH)D concentrations in premenopausal black and white women living in the New York City area. However, Bell et al. (1985) found lower $25(\mathrm{OH}) \mathrm{D}$ concentrations in young blacks living in South Carolina. In contrast to white subjects, black subjects did not show a rise in serum vitamin $\mathrm{D}$ and $25(\mathrm{OH}) \mathrm{D}$, following a single exposure to a relatively small ultraviolet radiation dose (Clemens et al. 1982). The observation is explained by lower previtamin $\mathrm{D}_{3}$ synthesis rate in pigmented skin (Holick et al. 1981).

The present study shows that placebo-controlled (postmenopausal Dutch women) and placebo-uncontrolled (postmenopausal Curaçao women and premenopausal Dutch women) administration of 10 or $20 \mu \mathrm{g}$ cholecalciferol/d for 4-5 weeks during late winter/early spring raised the concentration of $25(\mathrm{OH}) \mathrm{D}$ in the plasma of premenopausal and postmenopausal women living in a northern latitude (The Netherlands) to those of postmenopausal women living in the tropics (Curaçao). The similarity in response to supplementation with $10 \mu \mathrm{g} / \mathrm{d}$ and $20 \mu \mathrm{g} / \mathrm{d}$ suggests that the lower dose is adequate. It is conceivable that a smaller dose might have the same effect. The treatment had no effect on serum $\mathrm{Ca}$ and phosphate concentrations (all women), or on urinary $\mathrm{Ca}$ and phosphate excretion (Curaçao), which implies that no short-term toxic effects are likely to occur.

Vitamin-D toxicity has been reported when young children were given $45 \mu \mathrm{g}$ or more daily, but young children are especially sensitive to vitamin-D toxicity (National Research Council, 1989). A high concentration of $25(\mathrm{OH}) \mathrm{D}$ in plasma may play a role in this. The highest $25(\mathrm{OH}) \mathrm{D}$ level in the present study was $188 \mathrm{nmol} / 1$. Hypercalcaemia and hyperphosphataemia due to vitamin-D intoxication are usually accompanied by plasma 25(OH)D levels above $375 \mathrm{nmol} / 1$ (Holick, 1994).

Absolute increases of plasma $25(\mathrm{OH}) \mathrm{D}$ following 4-5 weeks cholecalciferol sup- 
plementation were similar in premenopausal and postmenopausal Dutch and postmenopausal Curaçao women. Taking all data together, the median $25(\mathrm{OH}) \mathrm{D}$ increase amounted to $24 \mathrm{nmol} / 1$. Our results indicate that in the 10,20 and $2 \times 20 \mu \mathrm{g}$ dose range the absolute $25(\mathrm{OH}) \mathrm{D}$ increase tended to some degree to be independent of baseline plasma $25(\mathrm{OH}) \mathrm{D}$, daily dose or frequency of administration of a given dose.

Similar effects of 10 and $20 \mu \mathrm{g}$ have been reported previously (Lips et al. 1988), and seem to argue against the notion that conversion of cholecalciferol to $25(\mathrm{OH}) \mathrm{D}$ is loosely regulated (Norman, 1990; Holick, 1994). Considering the similarity in $25(\mathrm{OH}) \mathrm{D}$ responses following a single 20 or a $2 \times 10 \mu$ g daily dose, it is hardly conceivable that in this dose range gastrointestinal fractional cholecalciferol absorption decreases with increasing cholecalciferol dose.

A possible explanation for the similarity in plasma $25(\mathrm{OH}) \mathrm{D}$ responses following 10 and $20 \mu \mathrm{g}$ cholecalciferol/d is that, like vitamin $\mathrm{E}$ and carotenoids (Traber \& Kayden, 1987; Kaplan et al. 1990), adipose tissue and other organs function as vitamin-D-buffering systems. Humans have the capacity to store circulating cholecalciferol, notably in adipose tissue and muscle (Mawer et al. 1972). Cholecalciferol taken orally probably leads to a different body distribution from that resulting from synthesis in skin. Cholecalciferol is believed to be removed from skin by binding to the vitamin-D-binding protein (Holick et al. 1981), whereas orally administered cholecalciferol enters the body via chylomicrons (Holick, 1994).

At present the effects of cholecalciferol are best described as maintenance of extracellular $\mathrm{Ca}$ and phosphate in a supersaturated state which results in bone mineralization (Holick, 1994). This thesis is supported by studies that showed beneficial effects of cholecalciferol supplementation in prevention or postponement of postmenopausal osteoporosis (DawsonHughes et al. 1991; Chapuy et al. 1992) and our observation that, in contrast to white women living in northern latitudes, postmenopausal white Curaçao women do not show signs of compression fractures of their lumbar vertebrae (Dubbelman et al. 1993). The young Dutch women had baseline PTH levels similar to those of the elderly Curaçao women, whereas those of the elderly Dutch women were higher (Table 1). Since high PTH levels are usually associated with bone $\mathrm{Ca}$ resorption, it is likely that premenopausal Dutch women (because of the protective influence of oestrogens on bone resorption) and postmenopausal Curaçao women (because of their better vitamin-D status) were in, or close to, bone $\mathrm{Ca}$ balance, whereas postmenopausal Dutch women (because of their lower vitamin-D status and lack of oestrogen protection) were in negative bone $\mathrm{Ca}$ balance.

Lips et al. (1988) reported $15 \%$ decreases of plasma PTH after 3 months cholecalciferol supplementation of two groups of elderly Dutch women (81 (SD 9) and 84 (SD 6) years) with very low baseline $25(\mathrm{OH}) \mathrm{D}$ levels $(23.6$ (SD 8.9) and 23.8 (SD 13.3) nmol/1 respectively). Their results and those of others (Dawson-Hughes et al. 1991; Chapuy et al. 1992) suggested that secondary hyperparathyroidism-induced bone $\mathrm{Ca}$ resorption diminished. We did not observe plasma PTH changes in postmenopausal Dutch women (mean 61 (SD 2) years) after 5 weeks cholecalciferol supplementation (Fig. 1(b)). Decrease of PTH may take longer than 5 weeks. Quite unexpectedly, cholecalciferol supplementation caused PTH to increase in premenopausal Dutch women (mean 30 (SD 7) years; Fig. 1(c)), and both PTH and $1,25(\mathrm{OH})_{2} \mathrm{D}$ to increase in postmenopausal Curaçao women (mean 75 (SD 6) years; Fig. 1(a)). The increase in plasma $1,25(\mathrm{OH})_{2} \mathrm{D}$ of premenopausal Dutch women did not reach statistical significance, probably because of the small number of subjects investigated. Because of oestrogen protection (premenopausal Dutch women) and high baseline vitamin D status (postmenopausal Curaçao women), we speculate that we are dealing with a natural reaction in women who are probably in bone Ca balance. Similar responses of PTH and $1,25(\mathrm{OH})_{2} \mathrm{D}$ were observed following administration of oestrogens to postmenopausal 
women. Stock et al. (1985) found that PTH (amino acids 44-68) concentration decreased after 2 weeks and subsequently increased after 8 weeks, whereas $1,25(\mathrm{OH})_{2} \mathrm{D}$ concentration was higher from 2 weeks.

In conclusion, this study shows that 4-5 weeks oral administration of 10 and $20 \mu \mathrm{g}$ cholecalciferol/d to premenopausal and postmenopausal white women in late winter/early spring causes plasma $25(\mathrm{OH}) \mathrm{D}$ to reach baseline levels characteristic of postmenopausal women living in the tropics. A daily dose of $10 \mu \mathrm{g}$ appears to be sufficient. The good condition of the lumbar vertebrae of postmenopausal white Curaçao women suggests that prevention of the decline in the plasma $25(\mathrm{OH}) \mathrm{D}$ in winter reduces bone demineralization of postmenopausal women living in northern latitudes (Jonxis, 1994).

\section{Note by Professor J. H. P. Jonxis added during editing}

The Committee on Nutrition of the Elderly of The Food and Nutrition Council of the Netherlands has recommended that men and women aged 65-75 years who are exposed to sunlight during the summer months should take a supplement of $2.5 \mu \mathrm{g}$ vitamin $\mathrm{D} / \mathrm{d}$. Those aged 65-75 years who are rarely exposed to sunlight, and all men and women aged over 75 years, should take a daily supplement of $7 \cdot 5-10 \mu \mathrm{g}$.

This study would not have been possible without the enthusiastic cooperation of the volunteers. We thank Dr J. M. Eustatia (Head of the Public Health Laboratory, Curaçao) for his hospitality and support. Many thanks go to all coworkers of the Department of Clinical Chemistry and Haematology (Curaçao), the Central Laboratory for Clinical Chemistry (Groningen), Dr J. J. Pratt and A. M. van Zanten. We also thank E. StatiusMuller and Elsien Soegies for their invaluable aid in the selection of volunteers in Curaçao and The Netherlands respectively. M. Volmer is acknowledged for performing the statistical analyses. We are very grateful to Dr E. M. Widdowson for her advice and for discussing the manuscript. The study was supported by the Netherlands Antilles Foundation for Clinical Higher Education (NASKHO) and Nutricia b.v., Zoetermeer, The Netherlands.

\section{REFERENCES}

Bell, N. H., Greene, A., Epstein, S., Oexmann, M. J., Shaw, S. \& Shary, J. (1985). Evidence for alteration of the vitamin D-endocrine system in blacks. Journal of Clinical Investigation 76, 70-73.

Chapuy, M. C., Arlot, M. E., Duboeuf, F., Brun, J., Crouzet, B., Arnoud, S., Delmas, P. D. \& Meunier, P. J. (1992). Vitamin $\mathrm{D}_{3}$ and calcium to prevent hip fractures in elderly women. New England Journal of Medicine $327,1637-1642$.

Clemens, T. L., Henderson, S. L., Adams, J. S. \& Holick, M. F. (1982). Increased skin pigment reduces the capacity of skin to synthesise vitamin $\mathrm{D}_{3}$. Lancet 1, 74-76.

Dawson-Hughes, B., Dallal, G. E., Krall, E. A., Harris, S., Sokoll, L. J. \& Falconer, G. (1991). Effect of vitamin D supplementation on wintertime and overall bone loss in healthy postmenopausal women. Annals of Internal Medicine 115, 505-512.

Dubbelman, R., Jonxis, J. H. P., Muskiet, F. A. J. \& Saleh, A. E. C. (1993). Age-dependent vitamin D status and vertebral condition of white women living in Curaçao (The Netherlands Antilles) as compared with their counterparts in The Netherlands. American Journal of Clinical Nutrition 58, 106-109.

Holick, M. F. (1994). Vitamin D. In Modern Nutrition in Health and Disease, 8th ed., pp. $308-325$ [M. E. Shils, J. A. Olsen and M. Shike, editors]. Philadelphia: Lea and Febiger.

Holick, M. F., MacLaughlin, J. A. \& Doppelt, S. H. (1981). Regulation of cutaneous previtamin D photosynthesis in man: skin pigment is not an essential regulator. Science 211, 590-593.

Jonxis, J. H. P. (1994). Correspondence. Nature 367, 404.

Jonxis, J. H. P., Saleh, A. E. C. \& Muskiet, F. A. J. (1993). Profylaxe van vitamine D grebrek bij volwassenen; op welke leeftijd beginnen en met welke dosis? (Prophylaxis of vitamin D shortage: at what age to start and at what dosage?) Nederlands Tijdschrift voor Geneeskunde 137, 843-846.

Kaplan, L. A., Lau, J. M. \& Stein, E. A. (1990). Carotenoid composition, concentrations and relationships in various human organs. Clinical Physiology and Biochemistry 8, 1-10. 
Khaw, K.-T., Sneyd, M.-J. \& Compston, J. (1992). Bone density, parathyroid hormone and 25-hydroxyvitamin D concentrations in middle aged women. British Medical Journal 305, 273-277.

Lips, P., Wiersinga, A., Van Ginkel, F. C., Jongen, M. J. M., Netelenbos, J. C., Hackeng, W. H. L., Delmas, P. D. \& van der Vijgh, W. J. F. (1988). The effect of vitamin D supplementation on vitamin D status and parathyroid function in elderly subjects. Journal of Clinical Endocrinology and Metabolism 67, 644-650.

Mawer, E. B., Backhouse, J., Holman, C. A., Lumb, G. A. \& Stanbury, S. W. (1972). The distribution and storage of vitamin D and its metabolites in human tissues. Clinical Science 43, 413-431.

Meier, D. E., Luckey, M. M., Wallenstein, S., Clemens, T. L., Orwoll, E. S. \& Waslien, C. I. (1991). Calcium, vitamin $\mathrm{D}$ and parathyroid hormone status in young white and black women: association with racial differences in bone mass. Journal of Clinical Endocrinology and Metabolism 72, 703-710.

Norman, A. W. (1990). Vitamin D. In Present Knowledge in Nutrition, 6th ed., pp. 108-116 [M. L. Brown, editor]. Washington, DC: International Life Sciences Institute Nutrition Foundation.

National Research Council, Food and Nutrition Board, Commission on Life Sciences (1989). Recommended Dietary Allowances, 10th ed. Washington, DC: National Academy Press.

Stevens, J. (1986). Applied Multivariate Statistics for the Social Sciences. London: Lawrence Erlbaum Associates.

Stock, J. L., Coderre, J. A. \& Mallette, L. E. (1985). Effects of a short course of oestrogen on mineral metabolism in postmenopausal women. Journal of Clinical Endocrinology and Metabolism 61, 595-600.

Traber, M. G. \& Kayden, H. J. (1987). Tocopherol distribution and intracellular localization in human adipose tissue. American Journal of Clinical Nutrition 46, 488495. 